\title{
Acute and persistent experimental nodavirus infection in spotted wolffish Anarhichas minor
}

\author{
R. Johansen ${ }^{1, *}$, M. Amundsen ${ }^{2}$, B. H. Dannevig ${ }^{1}$, A. I. Sommer ${ }^{2}$ \\ ${ }^{1}$ National Veterinary Institute, PO Box 8156, 0033 Oslo, Norway \\ ${ }^{2}$ Norwegian Institute of Fisheries and Aquaculture Research, 9291 Tromsø, Norway
}

\begin{abstract}
Spotted wolffish Anarhichas minor (approx. $0.7 \mathrm{~g}$ ) were found to be susceptible to infection with a nodavirus isolated from Atlantic halibut (AHNV) by bath-challenge. During the acute stage of infection, 4 to $8 \mathrm{wk}$ post-challenge, viral encephalopathy and retinopathy (VER) were diagnosed by histopathology, immunohistochemistry (IHC) and reverse transcriptase-polymerase chain reaction (RT-PCR). Accumulated mortality was $52 \%$ in the challenged group. The surviving fish were sampled $16 \mathrm{wk}$ post-challenge, by which time they had grown to approximately $17 \mathrm{~g}$. No clinical signs of VER were observed in these fish. RT-PCR examination revealed the presence of nodavirus in several organs of the survivors, but no immunopositive cells were detected by IHC. Nodavirus was reisolated from fish at the last sampling in SSN-1 cells, showing that nodavirus retains virulence in persistently infected wolffish for at least 16 wk post-bath-challenge.
\end{abstract}

KEY WORDS: Nodavirus · Viral encephalopathy and retinopathy - VER · Viral nervous necrosis . VNN $\cdot$ Spotted wolffish $\cdot$ Anarhichas minor

\section{INTRODUCTION}

Farming of spotted wolffish Anarhichas minor, along with other marine fish species such as Atlantic cod Gadus morhua, Atlantic halibut Hippoglossus hippoglossus and turbot Scophthalmus maximus are oncoming industries in Norway. Wolffish are in the Anarhichadidae family of the order Perciformes, which includes several other species known to be highly susceptible to nodavirus infection, e.g. striped jack Pseudocaranx dentex and sea bass Dicentrarchus labrax (Breuil et al. 1991, Mori et al. 1992). Nodaviruses cause viral encephalopathy and retinopathy (VER) and have been reported from more than 20 marine fish species in most parts of the world (Johnson et al. 2002, Munday et al. 2002). In the North Sea area, VER causes severe problems in farming of halibut, turbot and cod (Bloch et al. 1991, Grotmol et al. 1997, Starkey et al. 2001). Natural outbreaks of VER in wolffish have so far not been reported. Experimental studies have shown that spotted wolffish larvae ( 0.3 to $1 \mathrm{~g}$ ) are susceptible to nodavirus isolated from Atlantic halibut (AHNV) by bath-challenge, and nodavirus infections are a potential problem in the wolffish farming industry (Sommer et al. 2003). Transmission of nodavirus between different fish species is possible, and knowledge of potential cross infections is important in marine fish-farming management (Munday et al. 2002). Subclinically infected fish might serve as hidden nodavirus replication sites, and recently several reports have focused on the possibility of transmission of nodavirus from such fish (Castric et al. 2001, Barker et al. 2002, Johansen et al. 2002).

Fish nodaviruses belong to the family Nodaviridae and genus Betanodavirus (Ball et al. 2000). The virus particles are small (25 to $30 \mathrm{~nm}$ ), non-enveloped, icosahedral-shaped, contain single-stranded RNA, and the main target organ is the central nervous system (CNS) including brain, spinal cord and retina. Clinical signs of VER include lack of appetite, changes in pigmentation, neurological signs such as abnormal swimming, and mortality rates up to $100 \%$. In general, VER is diagnosed histologically by identification of necrosis and vacuolization in brain and retina combined with 
positive immunohistochemistry (IHC) for nodavirus. Enzyme-linked immunosorbent assays (ELISA) and reverse transcription-polymerase chain reaction (RTPCR) tests for nodaviruses have been developed, and aggregates of virus particles have been observed by transmission electron microscopy (TEM) (Office International des Epizooties [OIE] 2000). The nodavirus genome is composed of 2 positive-sense RNA segments: RNA1, encoding RNA replicase, and RNA2, encoding the capsid protein precursor. Based on the coat protein-sequence, fish nodaviruses are categorized into 4 genotypes (Nishizawa et al. 1995, Skliris et al. 2001). All nodavirus isolates from the North Sea have so far been placed in the BFNNV genotype (Grotmol et al. 2000, Starkey et al. 2001).

The aim of this study was to investigate the pathogenesis of nodavirus infection in spotted wolffish during the acute stage. We also investigated survivors of the disease outbreak $16 \mathrm{wk}$ post-bath-challenge (PBC) for pathological changes and presence of the nodavirus.

\section{MATERIALS AND METHODS}

Fish. We obtained 255 juvenile spotted wolffish of generation 2001 (mean weight $0.7 \mathrm{~g}$ ) from Troms Steinbit A/S, Senja, Norway. The fish were produced using eggs and milt from wild-caught broodstock held in captivity. The larvae were offered live feed (Artemia sp.) mixed with dry feed (Skretting Marin nutra granules) for approximately $4 \mathrm{wk}$, prior to weaning onto dry feed. The fish were held under a $24 \mathrm{~h}$ continuous-light regime in shallow raceways $(20 \times 20 \times 100 \mathrm{~cm})$ containing natural seawater (35 ppt salinity) of approximately $12^{\circ} \mathrm{C}$. Seawater was introduced at one end and flowed through the raceway at a rate of 2 to $31 \mathrm{~min}^{-1}$. The fish were monitored daily for signs of disease and mortality.

Virus preparation for challenge. The nodavirus (AHNV692/9/98) was isolated from Atlantic halibut juveniles during an outbreak of VER in a Norwegian fish farm (Dannevig et al. 2000). SSN-1 cells were inoculated at $20^{\circ} \mathrm{C}$ with a third passage of virus supernatant. When a pronounced cytopathic effect (CPE) was observed (Day 6 post-infection), the cell cultures were frozen and thawed once. Cell-culture fluids were harvested and clarified by centrifugation $(1500 \times g$ for $15 \mathrm{~min})$. Supernatants were collected and stored at $-80^{\circ} \mathrm{C}$ until challenge.

Infectious titer was determined by end-point dilution of supernatant in SSN-1 cells and calculated to $10^{7,6} \mathrm{TCID}_{50} \mathrm{ml}^{-1}$ (Kärber 1931). Infected cells were tested by an indirect immunofluorescence technique (IFAT) using a polyclonal antiserum K672 against AHNV according to Grove et al. (2003).
Challenge. The challenge experiment was performed at the Aquaculture Research Station in Tromsø with approval from the Animal Research Council. The fish were placed in 3 raceways containing seawater at $12^{\circ} \mathrm{C}$, and acclimatised for $4 \mathrm{~d}$ before challenge. Feeding was suspended $24 \mathrm{~h}$ prior to challenge. The fish in Raceway A (100 fish) and Raceway B (65 fish) were bath-challenged by adding the virus directly to the seawater, and the water flow was stopped for $2 \mathrm{~h}$ (final virus dose $=10^{5,6} \mathrm{TCID}_{50} \mathrm{ml}^{-1}$ ). For practical reasons, fish were sampled from all raceways. Raceway A was used for sampling fish for pathological studies, while Raceway B was used for recording mortality and randomly sampling for RT-PCR. In Raceway C, 55 fish were left unchallenged and served as controls. Sampled fish were killed by an overdose of benzocaine.

Cohabitants. The cohabitating fish $(\mathrm{n}=35)$ were added to the same Raceway $B$ as the bath-challenge fish $3 \mathrm{~d}$ post-challenge. The cohabitating fish were separated from the rest of the fish by an open-mesh barrier.

Histology and immunohistochemistry (IHC). We sampled 5 fish from the challenged groups and 3 fish from the control group weekly over the first $5 \mathrm{wk}$ PBC. A final sampling from all raceways was done at $16 \mathrm{wk}$ PBC. The fish were fixed whole (heads only at $16 \mathrm{wk}$ PBC) for at least $24 \mathrm{~h}$ in neutral phosphate-buffered $10 \%$ formalin and embedded in paraffin wax. Sections (1.5 to $2 \mu \mathrm{m})$ were stained with haematoxylin-eosin (HE) or immunostained.

Immunohistochemical detection of nodavirus was performed with a streptavidin-biotin-alkaline-phosphatase complex technique according to Grove et al. (2003) using the antiserum K672. The control fish served as negative controls for the experiment. As additional controls for each test, tissue sections from halibut known to be nodavirus-infected were stained either with nodavirus antiserum (positive control) or with pre-immune rabbit serum (negative control).

Total RNA isolation and RT-PCR for nodavirus. We sampled 5 fish randomly at 3 and 4 wk PBC, while 10 fish were sampled at 16 wk PBC from both challenged and cohabitating fish. In addition, 5 dead fish from the challenged group were sampled at $8 \mathrm{wk}$ PBC. From the control group, we sampled 3 fish 1 and $16 \mathrm{wk}$ post-challenge. Sampled fish were frozen whole at $-70^{\circ} \mathrm{C}$. From small fish ( 1 to $8 \mathrm{wk}$ post-challenge) the head (with brain and eyes) and abdominal organs (including intestine, liver and spleen) were examined separately. From larger fish (16 wk post-challenge) eyes, brain, kidney and abdominal organs were examined separately. The samples were homogenized in phosphate-buffered saline (PBS) (1:5) with a laboratory blender (Stomacher 80, England) before analysis.

Isolation of total RNA from the homogenized tissue was performed in accordance with the Qiagen RNeasy 
handbook. Concentrations of RNA were measured spectrophotometrically. Reverse transcription (RT) and DNA amplification were carried out in 1 tube using the Qiagen 1-step RT-PCR kit in the presence of $0.5 \mu \mathrm{g}$ total RNA, $0.5 \mu \mathrm{M}$ of the forward primer 5'-CTG-AAGATA-CAT-TCG-CTC-CAA-3' and $0.5 \mu \mathrm{M}$ of the reverse primer 5'-TAT-CCC-ATA-GCC-CCC-AGT-G-3'. The primers used correspond to a nucleotide sequence from RNA2 of AHNV (Grotmol et al. 2000). The RT step at $60^{\circ} \mathrm{C}$ for $30 \mathrm{~min}$ was followed by an initial step of $95^{\circ} \mathrm{C}$ for $15 \mathrm{~min}$, followed by 34 cycles of a 3 -temperature polymerase chain reaction $\left(94^{\circ} \mathrm{C}\right.$ for $45 \mathrm{~s}, 57^{\circ} \mathrm{C}$ for $45 \mathrm{~s}, 72^{\circ} \mathrm{C}$ for $60 \mathrm{~s}$ ), and ended with $72^{\circ} \mathrm{C}$ for $10 \mathrm{~min}$. RNA isolated from fish tissue known to be nodavirus-infected and nodavirus-free were used as positive and negative controls. A positive result was visualized as a distinct band of approximately $264 \mathrm{bp}$ on a $2 \%$ agarose gel by UV light following ethidium bromide staining.

Reisolation of nodavirus in SSN-1 cells. Tissue from a bath-challenged fish from the final sampling point was chosen for inoculation into SSN-1 cell culture according to Dannevig et al. (2000). Cultures exhibiting CPE were collected by low-speed centrifugation and examined for the presence of nodavirus using IFAT according to Grove et al. (2003).

\section{RESULTS}

\section{Clinical signs and mortality}

Signs of VER started 4 wk PBC with abnormal behavior and lack of appetite. The highest mortality rate was at 6 to 8 wk PBC (Fig. 1). The total accumu-

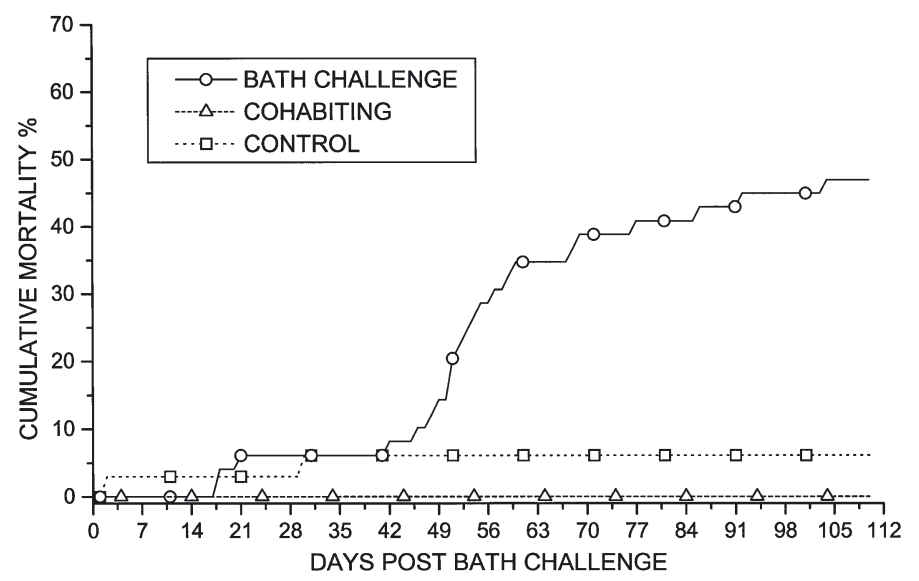

Fig. 1. Anarhichas minor. Cumulative mortality curves for the 3 groups of spotted wolffish. Control group was untreated. Bathchallenge fish were held in seawater containing nodavirus dose of $10^{5.6} \mathrm{TCID}_{50} \mathrm{ml}^{-1}$ for $2 \mathrm{~h}$. Cohabitating fish were added to the same tank as the bath-challenge fish $3 \mathrm{~d}$ post-challenge lated mortality in the bath-challenge group reached $52 \%$ whereas $9 \%$ died in the control group. The number of fish for calculation of the mortality rate was low, and the results should be regarded as estimates only. No disease or mortality was observed in the cohabitating group.

\section{Histopathology and immunohistochemistry}

CNS tissue was examined in all fish, while liver, kidney, spleen, pancreas, gills, heart, intestines, muscle and skin were examined in most fish $(\approx 80 \%)$. Abdominal organs showed moderate autolysis due to insufficient fixation. Small tissues such as ganglions, the pituitary gland, the thyroid gland, thymus and the sense cells in nose and ear were observed in a few sections. None of the examined fish from the control group showed any histopathology or positive immunolabeling.

Necrosis, vacuolation and positive immunolabeling for nodavirus in the CNS were detected in 5 fish 4 to 5 wk PBC (Table 1). All main parts of the brain and spinal cord were immunopositive for nodavirus (Figs. 2 \& 5), and vacuoles and immunopositive cells were seen even in the pituitary gland (Fig. 2b). In the retina, the inner nuclear cell layers and ganglion layers were heavily stained, while only a few positive cells were observed in the outer nuclear layers and pigment cell layers (Fig. 3). Only the growth zones of both retina and brain showed no immunopositive cells (Figs. 3 \& 4). No pathological changes or immunopositive cells were observed in organs outside the CNS. Even the ganglions along the brain and spinal cord tested negative (Figs. 2c \& 5). The remainder of the examined bath-challenged fish showed no histopathology or positive immunolabeling.

\section{RT-PCR}

None of the fish in the cohabitating or control-group fish tested positive. In the bath-challenged group, all 5 fish collected at 3 wk PBC tested negative, while 3 of

Table 1. Anarhichas minor. Number of samples from tissue of central nervous system testing positive for nodavirus by immunohistochemistry. Number of samples examined $=5$ except in final week, when 10 samples were tested. PBC: post-bath-challenge

\begin{tabular}{|cccccc|}
\hline \multicolumn{7}{c}{} & \multicolumn{2}{c|}{ No. of weeks PBC: } \\
\hline & 2 & 3 & 4 & 5 & 16 \\
\hline 0 & 0 & 0 & 3 & 2 & 0 \\
\hline
\end{tabular}




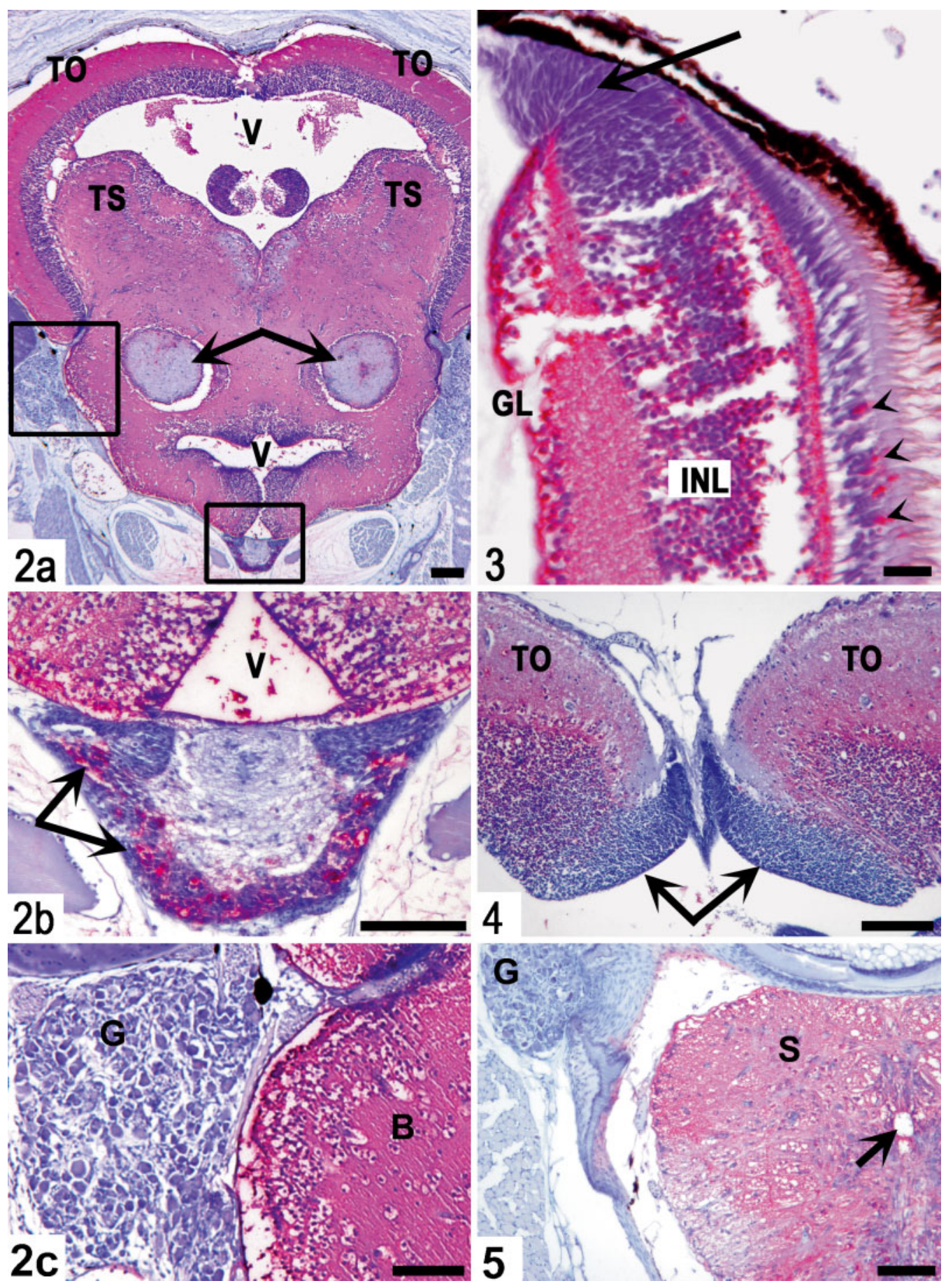

Figs. 2 to 5. Anarhichas minor. Spotted wolffish 4 wk post nodavirus bath-challenge. Light microscopic images of sections immunolabelled for nodavirus (red). Fig. 2a. Transverse section of brain through tectum opticums (TO) and torus semicircularis (TS); brain ventricle (V) appears both dorsally towards tectum opticum and ventrally toward pituitary gland (ventral inset); all parts of the brain were immunopositive; only a few immunopositive cells were seen in some round tissue structures in thalamus area (arrows); no immunopositive cells were seen in ganglions along brain (dorsal inset); scale bar $=200 \mu \mathrm{m}$. Fig. $2 \mathrm{~b}$. Higher magnification of ventral inset in $2 \mathrm{a}_{\text {; }}$ immunopositive cells visible in neural part of pituitary gland (arrows); scale bar $=100 \mu \mathrm{m}$. Fig 2c. Higher magnification of dorsal inset in 2a showing immunonegative ganglion (G) next to immunopositive brain tissue (B); $\overline{\text { scale }}$ bar $=100 \mu \mathrm{m}$. Fig. 3. Part of retina toward iris; ganglion cell layer (GL) and inner nuclear layers (INL) are strongly immunopositive; some immunolabeled cells also visible in outer nuclear cell layer (arrowheads); cells of circumferential growth zone (arrow) were immunonegative; scale bar $=20 \mu \mathrm{m}$. Fig. 4 . Tectum opticum (TO) of brain with immunonegative growth zones (arrows). Fig. 5. Immunonegative ganglion (G) next to immunopositive spinal cord (S); arrow shows central canal; scale bar $=100 \mu \mathrm{m}$ 
Table 2. Anarhichas minor. Number of samples from different organs testing positive for nodavirus with RT-PCR. Number of samples examined $=5$ except in final week when, 10 samples were tested. PBC: post-bath-challenge. Abd: abdominal organs including liver, spleen, pancreas and intestines

\begin{tabular}{|c|c|c|c|c|c|c|c|c|c|}
\hline \multirow{2}{*}{$\overline{\text { Head }}$} & \multirow{2}{*}{$3 \overline{\mathrm{Abd}}$} & \multirow{2}{*}{$\overline{\text { Head }}$} & \multirow{2}{*}{ Abd } & \multicolumn{4}{|c|}{ No. of weeks PBC: } & \multirow{2}{*}{ Kidney } & \multirow[b]{2}{*}{ Abd } \\
\hline & & & & Head & Abd & Eyes & Brain & & \\
\hline 0 & 0 & 3 & 2 & 4 & 1 & 10 & 9 & 7 & 5 \\
\hline \multicolumn{4}{|c|}{${ }^{\mathrm{a}}$ Only dead fish sampled } & & & & & & \\
\hline
\end{tabular}

the preferred experimental model for simulation of a natural infection. Susceptibility to experimental bath-challenge shows that the fish species is at risk of infection in farming conditions. Earlier studies on wolffish (10 g) gave $100 \%$ mortality ( $7 \mathrm{wk}$ at $7^{\circ} \mathrm{C}$ and $5 \mathrm{wk}$ at $12^{\circ} \mathrm{C}$ ) by intraperitoneal (i.p.) and intramuscular (i.m.) injection of homogenized tissue from nodavirus-infected halibut (Sommer et al. 2003). In the present study with $0.7 \mathrm{~g}$ fish held at $12^{\circ} \mathrm{C}$, mortality started $6 \mathrm{wk}$ PBC and 5 heads sampled 4 wk PBC were positive (Table 2). The 10 fish sampled at 16 wk PBC were larger, and it was possible to divide sampled tissues into separate samples of eyes, brain, kidney and abdominal organs (including intestine, liver and spleen). All 10 eye samples tested positive and only 1 brain sample was negative. Half of the samples from abdominal organs at $16 \mathrm{wk}$ PBC tested positive. The PCR product was sequenced to show that it corresponded to the virus used for challenge (results not shown).

\section{Reisolation of nodavirus in SSN-1 cells}

The fish chosen for reisolation of nodavirus tested positive by RT-PCR in all tested organs. Development of CPE was evident in the SSN-1 cells 7 to $12 \mathrm{~d}$ after inoculation with material from eyes, brain and abdominal organs. The kidney material displayed no CPE after 2 passages onto SSN-1 cells. All cell cultures with CPE tested positive for nodavirus by IFAT.

\section{DISCUSSION}

We have shown that spotted wolffish $(0.7 \mathrm{~g})$ are susceptible to nodavirus (AHNV) and develop classical signs of VER following experimental bath-challenge. Nodavirus was detected with IHC and RT-PCR in samples collected during the acute stage of infection. At the end of the experiment at $16 \mathrm{wk}$ PBC, all examined fish were subclinically infected, as revealed by RTPCR. The PCR product was sequenced to show that it corresponded to the virus used for challenge. Furthermore, nodavirus was reisolated from eyes, brain and abdominal organs at the end of the experiment, demonstrating the presence of infectious virus. These findings are of great importance to the future management of wolffish farming, since subclinical nodavirusinfected wolffish might spread the virus to other fishes.

Nodaviruses are believed to spread both horizontally between fishes and vertically from spawners to larvae (Breuil et al. 2000). Bath-challenge or cohabitation is only reached $52 \%$ at the end of the experiment at $16 \mathrm{wk}$. Several other studies in other species have also shown that challenge methods (bath, i.p./i.m. injection), fish age and water temperature are the major factors determining mortality rate (Peducasse et al. 1999, Husgard et al. 2001, Aranguren et al. 2002, Munday et al. 2002).

Nodaviruses infect neurons and are believed to spread along nerves (Nguyen et al. 1996). Cerebrospinal ganglia along the CNS could therefore be a possible target tissue. Several ganglions along the brain and spinal cord of nodavirus-infected wolffish were examined, but no immunopositive cells were detected. The neurons of the cerebrospinal ganglia are mostly sensorial, belonging to the somatic nerve system. Grotmol et al. (1999) reported immunopositive cells for nodavirus in ganglion cells adjacent to the otic capsule in Atlantic halibut larvae. This may have been the otic ganglion, a parasympathetic ganglion belonging to the cephalic ganglia. The results of Grotmol et al. (1999) also indicated that the caudal brain stem, containing nuclei of the parasympathetic vagus nerves, was the first part of the brain to become nodavirus-infected. These findings might indicate that the nodavirus mainly infects parasympathetic neurons. Somatic neurons of the cerebrospinal ganglia might lack receptors for nodavirus infection.

We were unable to detect nodavirus during the first $3 \mathrm{wk}$ PBC. The routes of nodavirus infection into the fish and into CNS are not known, but several studies indicate transport along nerves (Nguyen et al. 1996). In the infected wolffish, all parts of the retina and brain tested positive in the same individual fish samples as identified by IHC. The retinas were entirely positive in the inner nuclear layer (INL) and ganglion cell layer (GL), while only a few positive cells were seen in the outer nuclear layer (ONL) and pigment cell layer (PL). This could indicate that the virus reaches the inner nuclear layers of the retina by traveling along the nervous opticum from the brain. It is also possible that cells of the inner layers of the retina are more susceptible to nodavirus than cells of the outer layers. Several other studies also report that only, or primarily, the 
inner layers of the retina become infected by nodavirus (Peducasse et al. 1999, Husgard et al. 2001, Johansen et al. 2002, Grove et al. 2003).

Cells in the growth zones of the brain and retina showed no immunopositive staining for nodavirus in the present study. Growth zones have also tested negative with IHC in acute nodavirus-infected Atlantic halibut (Grotmol et al. 1999). It is possible that neural cells must reach a certain developmental stage before they become susceptible or before any numbers of virus are detectable by immunohistochemistry. Immunopositive cells in subclinically infected fish are often seen close to growth zones of the retina and brain (Husgard et al. 2001, Johansen et al. 2002, Grove et al. 2003). Further studies are necessary to reveal the relationship between susceptibility to nodavirus and cells at an early proliferation stage.

The pituitary gland (hypophysis) has a unique position connecting the nervous and endocrine systems, and it plays a major role in physiological homeostasis of both fishes and mammals. It consists of a neurological part (neurohypophysis) and an endocrine part (adenohypophysis) and has a central role in several neuroendocrine systems. Necrosis and vacuolation of cells in the pituitary gland might lead to several endocrine dysfunctions. 'The hypothalmo-pituitaryinterrenal axis', also called the 'hormonal stress-axis', interacts with the immune system of fishes, especially through excretion of andrenocorticotrophic hormone from the pituitary gland, resulting in increased cortisol production in the interrenal glands (Weyts et al. 1999). The interrenal glands are analogs to the adrenal cortex in mammals. In fishes, the interrenal glands are located in the head kidney, also one of the major organs for haematopoiesis, including leukocyte proliferation and antibody production. The proximity of the interrenal and hematopoietic tissue might indicate that the 'hormonal stress axis' is of greater importance in fishes than in mammals.

When a virus has reached the CNS it has passed most immune defenses, and virus replication within the CNS normally has severe consequences in mammals. Teleosts have the ability to produce new neurons as adults, and thus a continuous growth of the CNS throughout their lifetime (Zupanc \& Horschke 1995). Experimental studies of damaged retina in fishes have shown almost $100 \%$ regeneration (Hitchcock \& Raymond 1992). This ability of CNS regeneration makes it possible for fishes to show no sign of pathological change, even if severe changes were present earlier. The subclinically infected spotted wolffish 16 wk PBC showed no pathological changes, yet all fish were proven to be nodavirus-infected by RT-PCR. These subclinically infected fish might have survived an acute viremia and regenerated CNS, or perhaps never showed signs of disease. As long as fishes must be killed to enable VER diagnosis, it will be impossible to follow the course of infection in the same fishes at several samplings and thereby prove how they become subclinically infected. Individual registration of clinical signs of disease before sampling is 1 possibility that should be considered in subsequent experiments.

The horizontal spread of nodavirus from subclinically infected sea bream to cohabitating sea bass has been shown (Castric et al. 2001), but the routes of dispersal are not known. The reisolation of nodavirus from surviving fish indicates that spotted wolffish subclinically infected with nodavirus might be a source of infection. The negative cohabitants in our study indicate either that the infected wolffish did not spread enough nodavirus under the given circumstances, or that the cohabitating fish were not susceptible in the given situation. Nodavirus detection and mortality in the challenge group started 4 to 6 wk post-challenge. At this time the cohabitating fish might have developed to a stage that was no longer susceptible to bathchallenge. Stress factors, such as handling or low water flow, may be necessary both for spread and susceptibility of nodavirus at a postlarva stage.

Studies have shown that nodavirus strains from one fish species may have very different virulence towards other fish species (Totland et al. 1999, Castric et al. 2001). Totland et al. (1999) challenged Atlantic halibut with a nodavirus strain from striped jack and vice versa with negative results. Castric et al. (2001) showed that nodavirus from diseased sea bass could give a subclinical nodavirus infection in sea bream. Studies have also shown that 2 different nodavirus strains have been detected in sea bass from different parts of France (Thiery et al. 1999), and that the strains have varying pathogenicity to sea bass larvae of different age (Breuil et al. 2001). Water temperature seems to be a major factor in the success of cross-infection studies with different nodavirus isolates on different fish species (Aranguren et al. 2002, Munday et al. 2002). Munday et al. (2002) concluded that nodaviruses have low species-specificity. We challenged the wolffish with AHNV since this is the only nodavirus strain that has been isolated in Norway (Dannevig et al. 2000), and wolffish is a cold-water species like Atlantic halibut. Wolffish could be more susceptible to other nodavirus strains, and further challenge studies with other nodavirus strains would be of interest.

Acknowledgements. This work was supported by the Research Council of Norway, Grant 124210-110 and 124043-120. Sincere thanks to Saskia Mennen, Ingebjørg Modahl, Tone Kofstad and Randi Terland for their skilled technical assistance. Thanks to Peter A. Heuch and Torunn Taksdal for constructive criticism of the manuscript, and thanks to Duncan Colquhoun for correcting our English. 


\section{LITERATURE CITED}

Aranguren R, Tafalla C, Novoa B, Figueras A (2002) Experimental transmission of encephalopathy and retinopathy induced by nodavirus to sea bream, Sparus aurata L., using different infection models. J Fish Dis 25:317-324

Ball LA, Hendry DA, Johnson JE, Rueckert RR, Scotti PD (2000) Family Nodaviridae. In: Van Regenmortel MHV (ed) Virus taxonomy. Academic Press, San Diego, p 747-755

Barker DE, MacKinnon AM, Boston L, Burt MDB and 6 others (2002) First report of piscine nodavirus infecting wild winter flounder Pleuronectes americanus in Passamaquoddy Bay, New Brunswick, Canada. Dis Aquat Org 49:99-105

Bloch B, Gravinger K, Larsen JL (1991) Encephalomyelitis among turbot associated with a picornavirus-like agent. Dis Aquat Org 10:65-70

Breuil G, Bonami JR, Pepin JF, Pichot Y (1991) Viral-infection (picorna-like virus) associated with mass mortalities in hatchery-reared sea-bass (Dicentrarchus labrax) larvae and juveniles. Aquaculture 97:109-116

Breuil G, Pepin JF, Castric J, Fauvel C, Thiery R (2000) Detection of serum antibodies against nodavirus in wild and farmed adult sea bass: application to the screening of broodstock in sea bass hatcheries. Bull Eur Assoc Fish Pathol 20:95-100

Breuil G, Mouchel O, Fauvel C, Pepin JF (2001) Sea bass Dicentrarchus labrax nervous necrosis virus isolates with distinct pathogenicity to sea bass larvae. Dis Aquat Org 45:25-31

Castric J, Thiery R, Jeffroy J, de Kinkelin P, Raymond JC (2001) Sea bream Sparus aurata, an asymptomatic contagious fish host for nodavirus. Dis Aquat Org 47:33-38

Dannevig BH, Nilsen R, Modahl I, Jankowska M, Taksdal T, Press CM (2000) Isolation in cell culture of nodavirus from farmed Atlantic halibut Hippoglossus hippoglossus in Norway. Dis Aquat Org 43:183-189

Grotmol S, Totland GK, Thorud K, Hjeltnes BK (1997) Vacuolating encephalopathy and retinopathy associated with a nodavirus-like agent: a probable cause of mass mortality of cultured larval and juvenile Atlantic halibut Hippoglossus hippoglossus. Dis Aquat Org 29:85-97

Grotmol S, Bergh O, Totland GK (1999) Transmission of viral encephalopathy and retinopathy (VER) to yolk-sac larvae of the Atlantic halibut Hippoglossus hippoglossus: occurrence of nodavirus in various organs and a possible route of infection. Dis Aquat Org 36:95-106

Grotmol S, Nerland AH, Biering E, Totland GK, Nishizawa T (2000) Characterisation of the capsid protein gene from a nodavirus strain affecting the Atlantic halibut Hippoglossus hippoglossus and design of an optimal reversetranscriptase polymerase chain reaction (RT-PCR) detection assay. Dis Aquat Org 39:79-88

Grove S, Johansen R, Dannevig BH, Reitan LJ, Ranheim T (2003) Experimental infection of Atlantic halibut Hippoglossus hippoglossus with nodavirus: tissue distribution and immune response. Dis Aquat Org 53:211-221

Hitchcock PF, Raymond PA (1992) Retinal regeneration. Trends Neurosci 15:103-108

Husgard S, Grotmol S, Hjeltnes BK, Rodseth OM, Biering E (2001) Immune response to a recombinant capsid protein of striped jack nervous necrosis virus (SJNNV) in turbot Scophthalmus maximus and Atlantic halibut Hippoglossus

Editorial responsibility: Jo-Ann Leong,

Kaneohe, Hawaii, USA hippoglossus, and evaluation of a vaccine against SJNNV. Dis Aquat Org 45:33-44

Johansen R, Ranheim T, Hansen MK, Taksdal T, Totland GK (2002) Pathological changes in juvenile Atlantic halibut Hippoglossus hippoglossus persistently infected with nodavirus. Dis Aquat Org 50:161-169

Johnson SC, Sperker SA, Leggiadro CT, Groman DB, Griffiths SG, Ritchie RJ, Cook MD, Cusack RR (2002) Identification and characterization of a piscine neuropathy and nodavirus from juvenile Atlantic cod from the Atlantic coast of North America. J Aquat Anim Health 14:124-133

Kärber G (1931) Beitrag zur kollektiven Behandlung pharmakologischer Reihenversuche. Arch Exp Pathol Pharmakol 162:480-483

Mori K, Nakai T, Muroga K, Arimoto M, Mushiake K, Furusawa I (1992) Properties of a new virus belonging to Nodaviridae found in larval striped jack (Pseudocaranx dentex) with nervous necrosis. Virology 187:368-371

Munday BL, Kwang J, Moody N (2002) Betanodavirus infections of teleost fish: a review. J Fish Dis 25:127-142

Nguyen HD, Nakai T, Muroga K (1996) Progression of striped jack nervous necrosis virus (SJNNV) infection in naturally and experimentally infected striped jack Pseudocaranx dentex larvae. Dis Aquat Org 24:99-105

Nishizawa T, Mori K, Furuhashi M, Nakai T, Furusawa I, Muroga K (1995) Comparison of the coat protein genes of five fish nodaviruses, the causative agents of viral nervous necrosis in marine fish. J Gen Virol 76:1563-1569

Office International des Epizooties (OIE) (2000) Viral encephalopathy and retinopathy. In: Diagnostic manual for aquatic animal diseases. OIE, Paris p 69-73

Peducasse S, Castric J, Thiery R, Jeffroy J, LeVen A, Laurencin FB (1999) Comparative study of viral encephalopathy and retinopathy in juvenile sea bass Dicentrarchus labrax infected in different ways. Dis Aquat Org 36:11-20

Skliris GP, Krondiris JV, Sideris DC, Shinn AP, Starkey WG, Richards RH (2001) Phylogenetic and antigenic characterization of new fish nodavirus isolates from Europe and Asia. Virus Res 75:59-67

Sommer AI, Amundsen M, Rasmussen E, Mennen S (2003) Susceptibility of spotted wolffish Anarhichas minor to experimental infection with nodavirus and infectious pancreatic necrosis virus. Dis Aquat Org in press

Starkey WG, Ireland $\mathrm{JH}$, Muir KF, Jenkins ME, Roy WJ, Richards R, Ferguson HW (2001) Nodavirus infection in Atlantic cod and Doversole in the UK. Vet Rec 149: 179-181

Thiery R, Arnauld C, Delsert C (1999) Two isolates of sea bass, Dicentrarchus labrax L., nervous necrosis virus with distinct genomes. J Fish Dis 22:201-207

Totland GK, Grotmol S, Morita Y, Nishioka T, Nakai T (1999) Pathogenicity of nodavirus strains from striped jack Pseudocaranx dentex and Atlantic halibut Hippoglossus hippoglossus, studied by waterborne challenge of yolk-sac larvae of both teleost species. Dis Aquat Org 38:169-175

Weyts FAA, Cohen N, Flik G, Verburg-van Kemenade BML (1999) Interactions between the immune system and the hypothalamo-pituitary-interrenal axis in fish. Fish Shellfish Immunol 9:1-20

Zupanc GKH, Horschke I (1995) Proliferation zones in the brain of adult gymnotiform fish: a quantitative mapping study. J Comp Neurol 213-233

Submitted: February 12, 2003; Accepted: August 1, 2003

Proofs received from author(s): November 10, 2003 